\title{
Pelatihan Pementasan Virtual Seni Budaya Kelurahan Purbayan di Masa Pandemi Covid-19
}

\section{Vera Yuli Erviana ${ }^{1 *}$, Bambang Robiin ${ }^{2}$, Iis Suwartini ${ }^{3}$, Arif Ardy Wibowo ${ }^{4}$}

\author{
${ }^{1}$ Pendidikan Guru Sekolah Dasar, Universitas Ahmad Dahlan, Jalan Ki Ageng Pemanahan No. 19 Sorosutan \\ Yogyakarta 55164 \\ ${ }^{2}$ Teknik Informatika, Universitas Ahmad Dahlan, Jalan Ring Road Selatan, Tamanan, Banguntapan, Bantul Yogyakarta \\ 55166 \\ ${ }^{3}$ Pendidikan Bahasa dan Sastra Indonesia, Universitas Ahmad Dahlan, Jalan Ring Road Selatan, Tamanan, \\ Banguntapan, Bantul Yogyakarta 55166 \\ ${ }^{4}$ Ilmu Komunikasi, Universitas Ahmad Dahlan, Jalan Ring Road Selatan, Tamanan, Banguntapan, Bantul Yogyakarta \\ 55166
}

*Email koresponden: vera.erviana@pgsd.uad.ac.id

\section{ARTICLE INFO}

\section{Article history}

Received: 21 Nov 2021

Accepted: 14 Des 2021

Published: 31 Des 2021

\section{Kata kunci:}

Masa pandemi Covid-

19;

Pementasan virtual;

Seni dan budaya;

\section{Keyword:}

Art and culture;

Covid-19 pandemic;

Virtual staging;

\begin{abstract}
A B S T R A K
Background: Situasi saat pandemi Covid-19 memberikan dampak signifikan terhadap kegiatan seni budaya di Kelurahan Purbayan. Maka dari itu untuk menghidupkan eksistensi seni budaya di Kelurahan Purbayan dilakukan pementasan secara virtual agar kebudayaan tetap bisa dilestarikan. Tujuan dari pengabdian pada masyarakat ini adalah untuk melatih pementasan virtual seni budaya dalam recovery dampak covid19 terhadap keberlangsungan desa seni budaya di Kelurahan Purbayan. Metode: Mitra dari kegiatan ini yaitu masyakat yang berada di Kelurahan Purbayan, Kotagede, Yogyakarta. Jumlah peserta yang mengikuti kegiata ini yaitu 35 orang. Metode pelaksanaan dalam kegiatan pengabdian ini terdiri dari beberapa tahapan mulai dari sosialisasi, pelatihan, pendampingan dan evaluasi terkait pementasan virtual seni budaya. Hasil: Hasil kegiatan ini telah terjadi peningkatan pemahaman mitra sebesar $45,84 \%$ untuk para pemeran pementasan seni budaya dan sebesar $40 \%$ untuk tim kreatif. Para pelaku seni budaya dan tim kreatif sebagai sasaran kegiatan sangat antusias mengikuti kegitan pelatihan ini. Setelah pelatihan secara intensif maka mitra dapat secara mandiri melakukan pementasan virtual seni budaya. Kesimpulan: Peningkatan ini menunjukkan bahwa kegiatan pelatihan pementasan virtual seni budaya Kelurahan Purbayan berhasil dan meningkatkan pemahaman mitra.
\end{abstract}

\footnotetext{
A B S T R A C T

Background: The current situation of the covid-19 pandemic has a significant impact on cultural arts activities in Purbayan Village. Therefore, to liven up the existence of cultural arts in Purbayan Village, virtual staging is carried out so that culture can still be preserved. The purpose of this community service is to train the virtual staging of cultural arts in recovering the impact of covid-19 on the sustainability of cultural arts villages in Purbayan Village. Method: The partner of this activity is the community located in Purbayan Village, Kotagede, Yogyakarta. The number of participants who follow this event is 35 people. The method of implementation in this devotional activity consists of several stages ranging from socialization, training, mentoring and evaluation related to the virtual staging of cultural arts. Results: The results of this activity have been an increase in partner understanding by $45.84 \%$ for the cast of cultural arts performances and by $40 \%$ for creative teams. Cultural arts actors and creative teams as the target of activities are very enthusiastic following this training activity. After intensive training, partners can independently perform virtual staging of cultural arts. Conclusion: This increase shows that the virtual staging training activities of Purbayan Village cultural arts are successful and increase the understanding of partners.
} 
(c) 2021 by authors. Lisensi Jurnal Solma, UHAMKA, Jakarta. Artikel ini bersifat open access yang didistribusikan di bawah syarat dan ketentuan Creative Commons Attribution (CC-BY) license.

\section{PENDAHULUAN}

Kelurahan Purbayan berdiri pada tahun 1981 yang terbentuk dari empat Rukun Kampung (RK). Adapun RK tersebut antara lain RK Gedongan, RK Basen, RK Purbayan, dan RK Alun-Alun. Jumlah penduduk di Kelurahan Purbayan terdiri dari 10.176 jiwa (Suryani, 2018). Kelurahan Purbayan memiliki potensi wisata budaya yang tak lekang ditelan zaman. Kelurahan Purbayan berada di Kapanewon Kotagede yang merupakan The Old Capital City yang menyimpan adat, tradisi, dan sejarah mengenai lahirnya Kerajaan Mataram Islam (Hakim, 2018) (Prasetyadilaga \& Baiquni, 2016). Kelurahan Purbayan juga masih melestarikan adat dan tradisi yang ada seperti upacara adat, seni pertunjukan, dolanan anak, serta lahirnya berbagai paguyuban kesenian. Hingga saat ini sastra lisan terkait perkembangan sejarah Islam di Kotagede tetap dilestarikan. Hal tersebut terbukti para pemandu wisata masih menjaga budaya tutur dalam memandu wisatawan untuk mengenalkan perkembangan sejarah Islam di Kotagede (Anurogo et al., 2017; Pusporetno, 2014).

Seni, budaya, dan kerajinan mengalami perkembangan pesat sehingga oleh pemerintah setempat dicanangkan sebagai desa wisata. Hal tersebut dibuktikan dengan berdirinya sentra kerajinan di berbagai dusun di Desa Purbayan seperti kerajinan perak, kerajinan tanduk, dan pembuatan keris di Basen. Tradisi dan Kebudayaan Islam masih dilestarikan dengan baik di Desa Purbayan hingga saat ini. Kekhasan kuliner seperti kipo dan kembang waru serta jajanan pasar lainnya. Selain itu, terdapat kegiatan seni budaya di gelar setiap tahun diantaranya Festival Budaya di Kotagede dan Srawung Kampung (Fajri, 2015). Kegiatan tersebut menjembatani para pelaku seni untuk tetap eksis dalam melestarikan budaya serta ajang bagi pelaku UMKM untuk menggelar bazar. Kesenian tersebut diantaranya ketoprak ogleng yang mengangkat sejarah islam seperti "Babad Alas Mentaok," srandul, sendratari klasik dan kreasi modern, syiir Jawa Islami, mocopatan, karawitan, dalang, keroncong, dan teater.

Sanggar kebudayaan pun maju pesat yang dikenal dengan nama Sanggar Maharani. Seni pertunjukan di Purbayan memiliki pengaruh yang besar terhadap keberlangsungan desa budaya. Banyaknya seni budaya dan sentra kerajinan UKM menjadikan kelurahan purbayan sebagai salah satu tujuan wisata. Wisata yang ada di Purbayan berbasis budaya dan religi. Namun, sejauh ini pengelolaan seni dan budaya sebagai destinasi menuju desa wisata baru tahap rintisan. Keragaman budaya berasal dari kebudayaan suatu kelompok atau wilayah yang berbeda. Kebudayaan yang dimiliki sekelompok masyarakat akan membentuk kekhasan dari pada kelompok lainnya. Kebudayaan merupakan sesuatu hal yang tidak bisa dilepaskan oleh individu atau masyarakat untuk bertindak dan berfikir (Prasetya, 2013).

Pengelolaan dan promosi belum dilakukan dengan baik sehingga belum ada pendataan secara spesifik mengenai pengunjung pariwisata. Salah satu kegiatan seni dan budaya yang tetap dilestarikan dan menjadi produk wisata budaya dan religi adalah seni pertunjukan dan budaya tutur. Selama ini seni pertunjukan yang telah di jalankan baru satu pertunjukan yaitu Babas Alas Mentaok, sedangkan budaya tutur, belum dikemas dan terdokumentasi secara baik. Dari sisi pengunjung wisata, sering terdapat kunjungan baik dari wisatawan domestik maupun turis mancanegara yang berkunjung dan mempelajari kebudayan di Kelurahan Purbayan, namun karena pengelolaan yang belum baik, Paguyuban Kampung wisata tidak memiliki data secara pasti. Pada saat pandemik Covid-19 ini memberikan dampak yang signifikan terhadap kegiatan seni budaya di kelurahan Purbayan. Sejak adanya pandemic covid-19 seni budaya pertunjukan kehilangan eksistensinya. Maka dari itu untuk menghidupkan eksistensi seni budaya di Kelurahan Purbayan dilakukan pementasan secara virtual agar kebudayaan tetap bisa dilestarikan. 
Pementasan secara virtual merupakan fenomena yang baru yang unik saat ini. Hal ini sebagai wujud seni budaya baru yang berbeda dengan pementasan panggung secara konvensional. Pementasan virtual berbeda dengan pementasan yang berupa media rekaman. Pementasan virtual merupakan penggabungan antara seni pemanggungan konvensional dengan seni audio visual. Pementasan konvensional berupa pementasan yang dilakukan secara langsung sehingga ada interaksi dengan penonton, sedangkan seni audio visual memiliki banyak batasan dalam proses pementasannya. Adapun batasan tersebut antara lain ada batasan sudut pandang, batasan pergerakan kamera, dan batasan pencahayaan (Amriyeni, 2013). Pementaan vitual berbeda dengan film. Film merupakan pertunjukan teater yang di rekam dan di sajikan dalam media lain sedangkan pementasan virtual merupakan teater yang berlangsung secata live melalui media lain (Lim, 2008). Unsur-unsur pementasan terdiri atas naskah, pemain, sutradara, tata rias, tata biarama, tata panggung, tata lampu, dan tata suara (Hermawati, 2008). Unsur-unsur tersebut menjadi landasan pelatihan ini dalam pementasan virtual seni budaya. Dalam kegiatan pelatihan pementasan virtual ini menggunakan teknologi multimedia yang menggabungkan elemen teks, grafis, audio, dan video, untuk menyampaikan informasi tentang seni budaya (Mayer, 2017; Omodara \& Adu, 2014; Susilowati, 2018).

Salah satu kegiatan yang dapat dilakukan untuk membangkitkan geliat dan memotivasi pekerja seni budaya adalah dengan mensinergikan SDM dan teknologi secara virtual. Permasalahan yang terjadi di Kelurahan Purbayan antara lain: 1) kurangnya pemahaman masyarakat dalam pementasan virtual, 2) keterbatasan SDM yang mampu mengoperasikan pertunjukan secara virtual, dan 3) belum memiliki media sosial dalam pementasan seni secara virtual. Adapun mitra yang menjadi sasaran pelatihan ini adalah warga di Kelurahan Purbayan, Yogyakarta. Tujuan dari pelatihan dan pendampingan ini untuk melatih pementasan virtual seni budaya dalam recovery dampak covid-19 terhadap keberlangsungan desa seni budaya di Kelurahan Purbayan.

\section{MASALAH}

Masa Pandemic Covid-19 menuntut adanya sosial distancing. Salah satu dampaknya adalah dalam pementasan seni dan budaya yang selama ini membutuhkan interaksi dan pementasan menjadi kendala. Pementasan seni dan budaya harus mulai mengadaptasi teknologi seperti halnya pementasan virtual.

Tabel 1. Permasalahan dan Target Kegiatan

\begin{tabular}{ll}
\hline \multicolumn{1}{c}{ Permasalahan } & \multicolumn{1}{c}{ Target Kegiatan } \\
\hline $\begin{array}{l}\text { Kurangnya pemahaman masyarakat } \\
\text { dalam pementasan virtual }\end{array}$ & $\begin{array}{l}\text { Meningkatnya pemahaman masyarakat } \\
\text { dalam pengoperasian pertunjukan secara } \\
\text { virtual }\end{array}$ \\
$\begin{array}{l}\text { Keterbatasan SDM yang mampu } \\
\text { mengoperasikan pertunjukan secara } \\
\text { virtual }\end{array}$ & $\begin{array}{l}\text { SDM terampil dalam pertunjukkan secara } \\
\text { velum memiliki media sosial dalam } \\
\text { pementasan seni secara virtual. }\end{array}$ \\
\hline
\end{tabular}

\section{METODE PELAKSANAAN}

Sebagai solusi atas persoalan yang dihadapi oleh mitra, metode pelakasanaan yang pada kegiatan pengabdian ini adalah pelatihan. Khalayak sasaran dari kegiatan ini adalah pelaku seni dan budaya di kelurahan purbayan diantaranya adalah para pemeran pentas seni dan tim kreatif. Waktu pelaksanan kegiatan adalah mulai tanggal 20-30 juni 2021. Metode kegiatan ini terdiri dari 
beberapa tahap mulai dari sosialisasi, pelatihan, pendampingan dan evaluasi (Mulyaningsih et al., 2021).

Kegiatan sosialisasi bertujuan untuk memberikan gambaran kepada mitra mengenai pentingnya kegiatan pelatihan pementasan seni budaya kelurahan purbayan di Era Pandemic Covid-19. Pada kegiatan sosialisasi ini juga dilakukan koordinasi mengenai hal-hal apa saja yang diperlu dipersiapkan dalam pelaksanaan pelatihan pementasan virtual seni dan budaya di Kelurahan Purbayan. Sosialisasi dilaksanakan pada tanggal 20 Juni 2021. Kegiatan pelatihan pementasan virtual seni budaya Kelurahan Purbayan di Masa Pandemic Covid-19 dilaksanakan pada tanggal 28 dan 29 Juni 2021. Kegiatan pelatihan ini bertujuan untuk meningkatkan pemahaman mitra mengenai bagaimana melakukan pementasan secara virtual pertunjukan seni dan budaya saat Pandemi Covid-19.

Kegiatan pendampingan dilakukan untuk mendampingi mitra dalam melaksanakan pementasan virtual pertunjukan seni dan budaya di era Pandemic Covid-19. Kegiatan tersebut dilaksanakan pada tanggal 29 Juni 2021. Kegiatan evaluasi dilakukan untuk mengetahui tingkat keberhasilan dari kegiatan pelatihan dan menentukan rencana tindak lanjut dari kegiatan pelatihan. Data-data yang diperlukan untuk evaluasi diperoleh dengan memberikan kuisioner yang diberikan kepada mitra ketika sebelum dan sesudah pelatihan. Alur kegiatan dapat dilihat pada diagram berikut;

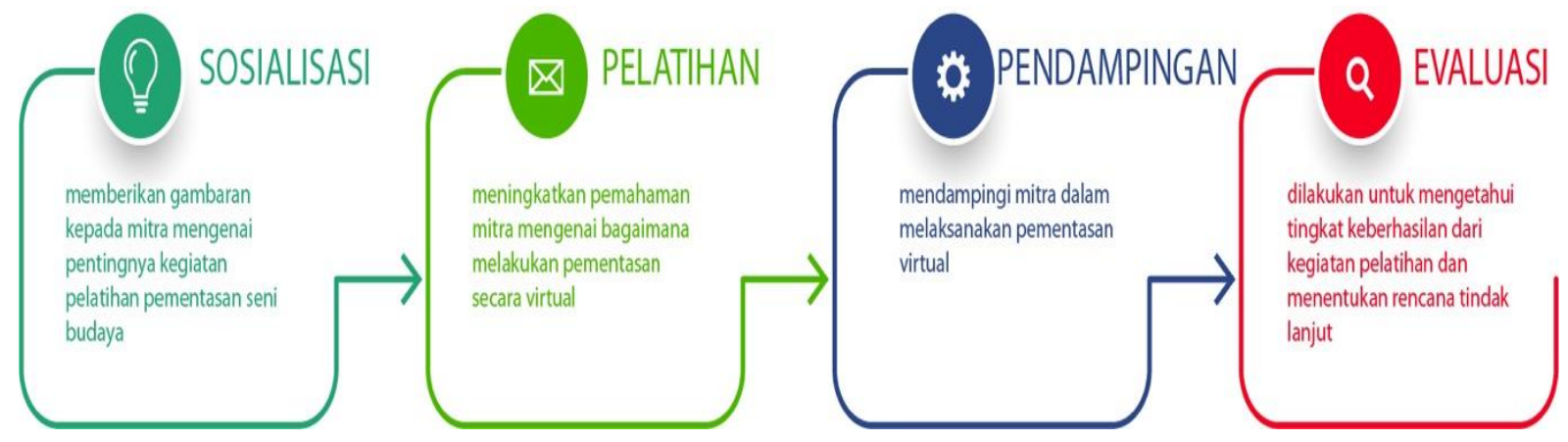

Gambar 1. Alur Kegiatan Pelatihan Pementasan Virtual Seni Budaya Kelurahan Purbayan Di Masa Pandemi Covid-19

\section{HASIL DAN PEMBAHASAN}

Kegiatan pengabdian kepada masyarakat berupa pelatihan pementasan virtual seni budaya Kelurahan Purbayan di era Pandemic Covid-19 dilaksanakan di Kampung Gedongan Kelurahan Purbayan. Secara keseluruhan kegiatan ini dilaksanakan pada tanggal 20 Juni 2021 sampai dengan tanggal 30 Juni 2021.

\section{Sosialisasi}

Kegiatan sosialisasi pelatihan pementasan virtual seni dan budaya kelurahan purbayan di masa pendemi covid-19 ini dilaksanakan pada tanggal 20 Juni 202. Kegiatan sosialisasi ini dilaksanakan untuk memberikan informasi mengenai pentingnya kegiatan pelatihan ini kepada ketua kampung, dan para pelaku seni dan budaya di Kelurahan Purbayan. Selain sosialisasi juga dilakukan kegiatan koordinasi pada tanggal 23 Juni 2021. Gambar 2 berikut ini adalah suasana kegiatan sosialisasi pelatihan pementasan virtual seni budaya Kelurahan Purbayan di masa Pandemi Covid-19. 


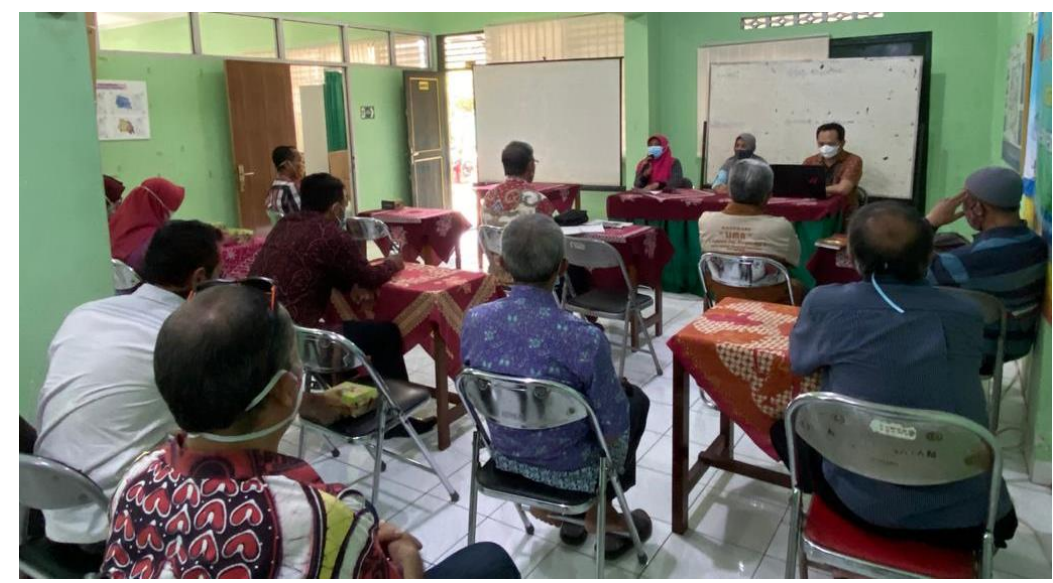

Gambar 2. Sosialisasi Pelatihan Pementasan Virtual Seni Budaya

Adapun hambatan kegiatan sosialisasi pelatihan pementasan virtual seni budaya di Kelurahan Purbayan antara lain:

1. Masyarakat yang mengikuti kegiatan sosialisasi ini hanya bisa diwakilkan oleh 2 peserta dari masing-masing kelompok di padukuhan.

2. Pemberlakuan waktu kegiatan terbatas sehingga penyampaian kurang maksimal, sehingga dilanjutkan pendampingan melalui grup whatsapp.

\section{Pelatihan dan Pendampingan}

Kegiatan pelatihan dan pendampingan pementasan virtual seni budaya di Kelurahan Purbayan pada saat Pandemic Covid-19 ini dilakukan untuk memberikan pemahaman kepada mitra mengenai bagaimana konsep pementasan virtual dan bagaimana mengemas pertunjukan seni budaya menjadi sebuah pertunjukan yang digelar pada saat pandemi covid-19. Pementasan virtual ini menjadi salah satu solusi ketika adanya pandemi covid-19 yang memberikan dampak kepada masyarakat untuk menjaga jarak dan menghindari berkerumun atau berkumpul sehingga pentas seni budaya yang semula dilaksakan pada sebuah pertunjukan yang dihadiri oleh banyak orang menjadi tidak dapat dilaksanakan.

Partisipasi masyarakat pada kegiatan pelatihan pementasan virtual seni budaya Kelurahan Purbayan di saat pandemic virus corona ini cukup besar. Kegiatan ini diikuti oleh 35 orang yang berasal dari dua kelompok yaitu 30 orang pelaku seni dan budaya (tokoh pemeran kesenian) dan lima orang sebagai tim kreatif yang bertugas untuk melakukan perekaman pementasan seni budaya.

Kegiatan pelatihan pementasan virtual seni budaya untuk pemeran atau pelaku seni dilakukan dengan memberikan pemahaman mengenai konsep pementasan virtual dan teknik bermain peran saat pengambilan gambar. Kegiatan pementasan virtual seni budaya untuk tim kreatif dilakukan untuk memberikan pemahaman tentang peralatan teknis untuk perekaman dan pementasan virtual, editing video, serta publikasi video. Kegiatan pelatihan dan pendampingan pementasan virtual seni budaya kelurahan purbayan ini dilaksanakan pada tanggal 28 dan 29 Juni 2021 (Gambar 3).

Adapun hambatan kegiatan pelatihan dan pendampingan pementasan virtual seni budaya di Kelurahan Purbayan yaitu masyarakat belum mampu beradaptasi dengan penggunaan alat dalam pementasan virtual sehingga membutuhkan pendampingan intensif dari tim pengabdian pada masyarakat.

\section{Evaluasi}

Evaluasi kegiatan dilaksanakan untuk mengetahui tingkat keberhasilan dari kegiatan pelatihan pementasan virtual seni budaya Kelurahan Purbayan pada masa pandemic Covid-19 ini. 
Selain itu kegiatan evaluasi juga dilakukan untuk menentukan tindak lanjut dari kegiatan ini. Adapun hambatan kegiatan evaluasi pelatihan pementasan virtual seni budaya di Kelurahan Purbayan yaitu masyarakat belum mampu menghadirkan pertunjukkan virtual dengan baik, terutama pada editing video.


Gambar 3. Pelatihan dan Pendampingan Pementasan Virtual Seni Budaya

Untuk mengukur tingkat keberhasilan kegiatan dilakukan dengan memberikan kuesioner sebelum dan sesudah pelatihan yang digunakan untuk mengukur tingkat pemahaman mitra. Perbandingan hasil kuesioner sebelum dan sesudah pelatihan merupakan peningkatan pemahaman mitra. Tabel 2 berikut ini merupakan hasil kusioner sebelum dan sesudah pelatihan untuk pemeran pementasan.

Tabel 2. Peningkatan Pemahaman Pemeran Pementasan

\begin{tabular}{|c|c|c|c|}
\hline Pertanyaan & $\begin{array}{l}\text { Pre Test } \\
(\%)\end{array}$ & $\begin{array}{c}\text { Post Test } \\
(\%)\end{array}$ & $\begin{array}{l}\text { Peningkatan } \\
(\%)\end{array}$ \\
\hline Pemahaman Pemeran mengenai konsep pementasan virtual & $33,33 \%$ & $90 \%$ & $56,67 \%$ \\
\hline $\begin{array}{l}\text { Pemahaman pemeran tentang peralatan audio video yang } \\
\text { digunakan dalam perekaman }\end{array}$ & $43,33 \%$ & $76,67 \%$ & $33,34 \%$ \\
\hline $\begin{array}{l}\text { Pemahaman pemeran tentang teknik bermain peran ketika } \\
\text { di depan kamera }\end{array}$ & $46,67 \%$ & $90 \%$ & $43,33 \%$ \\
\hline $\begin{array}{l}\text { Pemahaman pemeran optimalisasi suara pada saat } \\
\text { pengambilan video }\end{array}$ & $33,33 \%$ & $83,33 \%$ & $50 \%$ \\
\hline Rata-rata & $39,16 \%$ & $85 \%$ & $45,84 \%$ \\
\hline
\end{tabular}

Pada Tabel 2 menunjukkan bahwa telah terjadi peningkatan mitra khususnya para pemeran pementasan mengenai pementasan virtual seni budaya Kelurahan Purbayan Di Masa Pandemi Covid-19 sebesar 45,84\%. Pada akhir pelatihan, tingkat pemahaman mitra mencapai $85 \%$. Hal ini menunjukan bahwa kegiatan pelatihan pementasan virtual seni budaya kelurahan purbayan di masa pandemi covid-19 untuk para pemeran pementasan ini telah berhasil dilakukan.

Namun, ada salah satu kebijakan pemerintah dalam penanganan penyebaran covid-19 melalui pembatasan kegiatan masyarakat termasuk dalam hal pementasan. Kebijakan ini memberikan dampak menurunnya para pekerja seni musik karena tidak dapat melakukan pertunjukan. Salah satu upaya yang dilakukan para pekerja seni agar tetap eksis dan dapat bertahan hidup ditengah pandemi adalah dengan melakukan pementasan secara virtual. Pementasan tersebut dilaksanakan menggunakan berbagai sosial media seperti youtube, facebook, dan Instagram (Fatimah \& Hayati, 2021). Kegiatan atau upaya ini memberikan hasil yang baik sehingga para pekerja seni dapat bertahan di tengah pandemi covid-19. Dalam pementasan virtual, sebaiknya memperhatikan unsur-unsur sinematik yang meliputi mis-en-scene, sinematografi, dan suara. Untuk memenuhi unsur-unsur sinematik, pekerja seni harus menguasai 
peralatan baik kamera maupun audio yang dimiliki. Pementasan tidak harus didukung dengan peralatan yang berkampuan tinggi, tetapi dengan memahami batas-batas kemampuan alat, pementasan virtual dapat dilakukan dengan optimal (Suharijadi, 2021).

Pelatihan pementasan virtual seni budaya untuk tim kreatif juga memiliki peningkatan yang cukup signifikan. Tabel 3 berikut ini merupakan hasil kuisioner sebelum dan sesudah pelatihan yang menunjukkan tingkat pemehaman mitra.

Tabel 3. Peningkatan Pemahaman Tim Kreatif

\begin{tabular}{|c|c|c|c|}
\hline Pertanyaan & $\begin{array}{c}\text { Pre Test } \\
(\%)\end{array}$ & $\begin{array}{c}\text { Post Test } \\
(\%)\end{array}$ & $\begin{array}{l}\text { Peningkatan } \\
(\%)\end{array}$ \\
\hline Pemahaman mitra mengenai konsep pementasan virtual & $40 \%$ & $100 \%$ & $60 \%$ \\
\hline $\begin{array}{l}\text { Pemahaman mitra mengenai peralatan audio video yang } \\
\text { digunakan dalam perekaman }\end{array}$ & $60 \%$ & $80 \%$ & $20 \%$ \\
\hline $\begin{array}{l}\text { Pemahaman mitra mengenai teknik pengembilan video dan } \\
\text { audio saat pementasan }\end{array}$ & $60 \%$ & $100 \%$ & $40 \%$ \\
\hline $\begin{array}{l}\text { Pemahaman mitra mengenai proses editing audio dan } \\
\text { video pasca perekaman }\end{array}$ & $40 \%$ & $80 \%$ & $40 \%$ \\
\hline Pemahaman mitra mengenai publikasi hasil perekaman & $60 \%$ & $100 \%$ & $40 \%$ \\
\hline Rata-rata & $52 \%$ & $92 \%$ & $40 \%$ \\
\hline
\end{tabular}

Tabel 3 menunjukkan bahwa telah terjadi peningkatan pemahaman mitra khususnya tim kreatif mengenai pementasan virtual seni budaya kelurahan purbayan di masa pandemic covid-19 ini sebesar $40 \%$. Pada akhir pelatihan tingkat pemahaman mitra secara rata-rata mencapai $92 \%$. Hal ini menunjukkan bawa pelatihan pementasan virtual seni budaya untuk tim kreatif telah berhasil dilakukan.

\section{KESIMPULAN}

Secara keseluruhan kegiatan pengabdian masyarakat dengan judul pelatihan pementasan virtual seni budaya Kelurahan Purbayan di Masa Pandemi Covid-19 ini telah berjalan dengan baik. Para pelaku seni budaya dan tim kreatif sebagai sasaran kegiatan sangat antusias mengikuti kegitan pelatihan ini. Kegiatan ini telah berhasil meningkatkan pemahaman mitra, baik pemeran maupun tim kreatif. Peningkatan ini menunjukkan bahwa kegiatan pelatihan ini telah berhasil sesuai dengan tujuan yang diharapkan. Keberlanjutan program PPM di Kelurahan Purbayan ini adalah 1) terselenggaranya pentas virtual secara mandiri oleh pelaku budaya dan tim kreatif, 2) terjalinnya kerjasama dengan dinas pariwisata, dan 3) terselenggaranya pentas budaya secara mandiri. Tantangan dari program ini yakni kesadaran masyarakat yang masih minim tentang pentas virtual dan keterbatasan literasi sehingga memerlukan pendampingan yang intensif.

\section{UCAPAN TERIMA KASIH}

Ucapan terimakasih disampaikan kepada LPPM (Lembaga Penelitian dan Pengabdian Masyarakat) Universitas Ahmad Dahlan yang telah memberikan dukungan dan pendanaan pada kegiatan pengabdian kepada masyarakat ini. Terimakasih juga disampaikan kepada kelurahan Purbayan atas kerjasamanya dan kepada mitra pelaku seni dan budaya atas per sertanya.

\section{DAFTAR PUSTAKA}

Amriyeni, M. (2013). Pengaruh Audio Visual Terhadap Hasil Belajar Siswa Dalam Pembelajaran Tari Daerah Setempat Kelas X SMA Negeri 8 Padang. E-Jurnal Sendratasik FBS Universitas Negeri Padang, 2(1), 56-62.

Anurogo, W., Lubis, M. Z., Hartono, Pamungkas, D. S., \& Dilaga, A. P. (2017). Ketahanan Kawasan Wisata Berbasis Masyarakat Dalam Penguatan Ekonomi Lokal Dan Pelestarian Sumberdaya Kebudayaan 
Kawasan Kotagede Yogyakarta. JURNAL KETAHANAN NASIONAL, 23(2), 114-136. https://doi.org/http://dx.doi.org/10.22146/jkn.25929

Fajri, C. (2015). PERSEPSI MASYARAKAT KOTAGEDE TERHADAP PENGGUNAAN MEDIA KOMUNIKASI OLEH ORGANISASI FORUM JOGLO UNTUK PELESTARIAN BUDAYA DI KOTAGEDE YOGYAKARTA. Humanika, 15(1), 49-65.

Fatimah, N., \& Hayati, E. H. (2021). Adaptasi Pekerja Seni Musik Dangdut di Masa Pandemi COVID - 19. Jurnal Litbang: Media Informasi Penelitian, Pengembangan Dan IPTEK, 17(1), 35-46. https://doi.org/https://doi.org/10.33658/j1.v17i1.244

Hakim, M. F. N. (2018). Pelestarian Kotagede Sebagai Pusat Pariwisata Heritage Kota Tua Di Yogyakarta. Khasanah Ilmu - Jurnal Pariwisata Dan Budaya, 9(1). https://doi.org/10.31294/khi.v9i1.2805

Hermawati, S. (2008). Seni Budaya Jilid 2 untuk SMK. Direktorat Pembinaan Sekolah Menengah Kejuruan, Direktorat Jenderal Manajemen Pendidikan Dasar dan Menengah, Departemen Pendidikan Nasional.

Lim, F. (2008). Filsafat Teknologi Tentang Manusia \& Alat. Kanisius.

Mayer, R. (2017). Using Multimedia for e-learning. Journal of Computer Assested Learning, 33(5), 403-423. https://doi.org/https://doi.org/10.1111/jcal.12197

Mulyaningsih, N. N., Saraswati, D. L., \& Ningsih, R. (2021). Pelatihan Penggunaan Youtube sebagai Media Pembelajaran Jarak Jauh di Era COVID-19. S $O \quad L \quad M \quad A, \quad$ 10(02), 329-337. https://doi.org/https://doi.org/10.22236/solma.v10i2.6021

Omodara, \& Adu. (2014). Relevance of Educational Media and Multimedia Technology for Effective Service Delivery in Teaching and Learning Processes. IOSR Journal of Research \& Method in Education (IOSRJRME), 4(2), 48-51. https://doi.org/10.9790/7388-04214851

Prasetya, J. T. (2013). Ilmu Budaya Dasar. Rineka Cipta.

Prasetyadilaga, A., \& Baiquni, M. (2016). Pengelolaan Paket Wisata Budaya Kotagede Yogyakarta. Jurnal Bumi Indonesia, 5(3), 1-6.

Pusporetno, M. (2014). Kotagede Sebagai Kawasan Wisata Budaya Dan Sejarah, Wisata Spiritual, Wisata Kuliner Dan Belanja. Pariwisata Dan Ekonomi, 1(1), 8.

Suharijadi, D. (2021). Pementasan Daring: Kaidah Baru dalam Penyajian Seni Pertunjukan. Susastra: Jurnal Ilmu Susastra Dan Budaya, 10(1), 12-21.

Suryani, A. (2018). Kelurahan Purbayan. Retrieved from Gambaran Umum Kelurahan Purbayan. 2018, Desember 15. https://purbayankel.jogjakota.go.id/page/index/gambaran-umum

Susilowati, T. (2018). Learning Application of Lampung Language Based on Multimedia Software. International Journal of Engineering and Technology, 7(27), 175-181. https://doi.org/https://doi:10.14419/ijet.v7i2.27.9942 